\title{
DETECTION OF HPV DNAAND IMMUNOHISTOCHEMICAL EXPRESSION OF CELL CYCLE PROTEINS IN ORAL CARCINOMA IN A POPULATION OF BRAZILIAN PATIENTS
}

\author{
Rosilene Calazans SOARES', Márcio Campos OLIVEIRA², Lélia Batista de SOUZA ${ }^{3}$ Antônio de Lisboa Lopes COSTA², \\ Leão Pereira PINTO ${ }^{3}$
}

1- DDS, MSc, PhD, Professor, Department of Morphology, Federal University of Sergipe, Aracaju, SE, Brazil.

2- DDS, MSc,PhD, Professor, Department of Oral Pathology, State University of Feira de Santana, Feira de Santana, BA, Brazil.

3- DDS, MSc,PhD, Professor, Department of Oral Pathology, Federal University of Rio Grande do Norte, Natal, RN, Brazil.

Corresponding address: Prof. Dr. Leão Pereira Pinto - Faculdade de Odontologia, Disciplina de Patologia Oral, Av. Salgado Filho, 1787, Lagoa Nova, 59056-000 Natal, RN, Brasil - Phone/Fax: +55-84-3215-4108 - e-mail: leão@pesquisador.cnpq.br.

Received: August 17, 2007 - Modification: October 10, 2007 - Accepted: March 3, 2008

\begin{abstract}
$T$

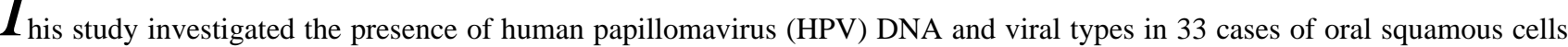
carcinoma (OSCC) and compared the immunohistochemical expression of the cell-cycle markers p21 and pRb between cases of the disease with and without HPV. DNA was extracted from paraffin-embedded tissue and amplified by PCR for the detection of HPV DNA. Viral typing was performed by dot blot hybridization. Immunohistochemistry was performed by the streptavidinbiotin technique. HPV DNA was detected in 11 (33.33\%) of the 33 cases. The prevalent viral type was HPV 18 (81.81\%). A significant association was observed between the presence of HPV and immunohistochemical expression of pRb, but not between p21 expression and the presence of the virus. The low frequency of detection of HPV DNA in OSCC suggests a possible participation of the virus in the development and progression of only a subgroup of these tumors.
\end{abstract}

Key words: DNA Probes. HPV. Carcinoma. Squamous cell cancer. Polymerase Chain Reaction. Hybridization. Cell cycle.

\section{INTRODUCTION}

Various studies have investigated the role of human papillomavirus (HPV) in oral squamous cells carcinoma (OSCC) but the results are highly controversial. Most reports have shown that HPV 16 is the most prevalent type in both oral and genital tumors ${ }^{1}$.

Abnormalities in several components of the cell-cycle regulatory machinery have been observed in oral cancers as well as in other types of cancer. Protein p21 is a universal inhibitor of cyclin-dependent kinases (CDKs) that mediates cell cycle arrest in the G1 and G2/M phase to prevent DNA replication in cells in which this molecule is damaged. Protein $\mathrm{pRb}$ plays an important role in cell-cycle regulation. When cells are stimulated by growth factors, this protein is inactivated by phosphorylation and cells progress from the $\mathrm{G} 1$ to the $\mathrm{S}$ phase. The hyperphosphorylated form of $\mathrm{pRb}$ releases E2F transcription factors which, in turn, activate the transcription of various target genes ${ }^{17}$.

In view of the importance of HPV in carcinogenesis, the objective of this study was to investigate the presence of HPV DNA and the most frequent viral types in patients with
OSCC, and to compare the immunohistochemical expression of the cell-cycle proteins p21 and pRb between HPV-positive and HPV-negative cases in order to establish a possible correlation between the expression of these proteins and HPV infection in OSCC.

\section{MATERIALAND METHODS}

Thirty-three cases of OSCC were retrieved from the 19962004 pathology service archives of the Department of Dentistry of the Federal University of Rio Grande do Norte and Hospital Dr. Luis Antônio, both in the city of Natal, RN, Brazil. Eligible cases were males or females aged 30 years or older (mean age $=65.45$ years; range $=30-93$ years) with newly diagnosed, histologically confirmed OSCC and not submitted to any kind of therapy (chemotherapy, radiotherapy or surgery). Topographic locations included malignancies of the tongue, gingiva, floor of mouth, palate, buccal mucosa, retromolar area and lip.

The presence of HPV DNA and immunohistochemical expression of proteins p21 and pRb were studied in 
specimens fixed in formalin and embedded in paraffin. Ten $10-\mu \mathrm{m}$ histological sections were used for the study of HPV, two 3- $\mu$ m sections were stained with hematoxylin and eosin for histopathological analysis, and two 3- $\mu$ m sections were submitted to immunohistochemistry.

DNA was extracted using the ammonium acetateisopropanol technique. This method was developed by the research team of the Laboratory of Molecular Biology of the Dental School of the University of São Paulo (USP) $)^{10}$ and consisted of the initial removal of paraffin by baths in xylene heated to $65^{\circ} \mathrm{C}$ followed by hydration of the tissues in a decreasing ethanol series (absolute, 95\%, 70\% and 50\%). Then, $400 \mu \mathrm{L}$ sterile lysis buffer $(50 \mathrm{mM} \mathrm{NaCl}, 5 \mathrm{mM}$ Tris$\mathrm{HCl}, \mathrm{pH}$ 8, $12.5 \mathrm{mM}$ EDTA, pH 8, and 0.25\% SDS) and proteinase $\mathrm{K}$ at a final concentration of $500 \mu \mathrm{g} / \mathrm{mL}$ were added to the tissue pellet of each sample and the samples were incubated at $55^{\circ} \mathrm{C}$ for 3 to 5 days until complete dissolution of the material. Next, $200 \mu \mathrm{L}$ of a $4 \mathrm{M}$ ammonium acetate solution were added to each sample for protein precipitation, followed by $600 \mu \mathrm{L} 100 \%$ isopropanol for DNA precipitation. Finally, the DNA pellets obtained were washed with $70 \%$ ethanol, dissolved in $50 \mu \mathrm{L}$ TE buffer and stored at $-20^{\circ} \mathrm{C}$.

The samples were submitted to polymerase chain reaction (PCR) to evaluate the efficacy of DNA extraction. For this, a pair of primers designated PCO3+ (5'CTTCTGACACAACTGTGTTCACTAGC3') and PCO4+ (5'TCACCGCAAC TTCATCCACGTTCACC3') was used which flank a 110-bp sequence of the human b-globin gene present in all human cells ${ }^{12}$. The reaction was carried out in an Eppendorf thermocycler (Eppendorf, Netherler, Hamburg, Germany).

Samples positive for the $\beta$-globin gene were analyzed by PCR regarding the presence of HPV DNA using a pair of generic primers called GP5+ (5'TTTGTTACTGTGGTAGATACTAC3') and GP6+ (5'GAAAAATA AACTGTAAATCAT ATTC3') ${ }^{11}$, which flank a fragment of about 140 bp of the L1 gene, a highly conserved sequence in the genome of mucosal (genital and oral) HPVs. The use of this primer pair permits the detection and amplification of this DNA segment from at least 23 individual mucosal (genital and oral) HPV types, including high risk HPV types.

The reaction mixture contained $1.0 \mu \mathrm{M}$ GP5+/GP6+ (Invitrogen, Life Technologies, Carlsbad, California), 1.0 U Taq DNA polymerase (Biosystems, New Jersey, USA), 20 mM Tris-HCl, pH 8.4, 50 mM KCl, 1.5 mM MgCl2, $200 \mu \mathrm{M}$ dNTP (Amersham Bioscience, Bucknghamshire, UK), and 0.7 to $7.0 \mu \mathrm{L}$ DNA, in a final volume of $50 \mu \mathrm{L}$. The PCR conditions for detection of HPV were: initial denaturation at $95^{\circ} \mathrm{C}$ for $5 \mathrm{~min}$, followed by 40 cycles of amplification at $95^{\circ} \mathrm{C}$ for $1 \mathrm{~min}, 45^{\circ} \mathrm{C}$ for $2 \mathrm{~min}$ and $72^{\circ} \mathrm{C}$ for $1.5 \mathrm{~min}$, and a final extension step at $72^{\circ} \mathrm{C}$ for $10 \mathrm{~min}$. Typing was done with dot blot hybridization ${ }^{13}$. Each dot blot membrane included several negative and positive controls for HPV types, as well as PCR products from patients and controls. The membrane was hybridized overnight as $56^{\circ} \mathrm{C}$ in $2 \mathrm{x}$ standard saline citrate (SSC), $0.5 \%$ sodium dodecylsulfatte (SDS) and $200 \mu \mathrm{g} / \mathrm{mL}$
DNA with 19 HPV types probes $(6,11,16,18,31,33,34,35$, $39,40,42,43,44,45,51,52,54,56,58)$, most common in mucosal (genital and oral), and label $\left[{ }^{32} \mathrm{P}\right] \mathrm{dATP}$. After hybridization, the unbound probe was of 2x SSC and $0.5 \%$ SDS at room temperature and two 10-min washes of the same solution at $56^{\circ} \mathrm{C}$. The membrane was exposed to $\mathrm{x}$-ray film at $-20^{\circ} \mathrm{C}$ for $24 \mathrm{~h}$.

For immunohistochemical analysis, the sections were dewaxed in xylene, rehydrated in decreasing ethanol series, and rinsed in water. In order to inhibit endogenous peroxidade activity, the sections were treated by immersion in 5 changes of $0.3 \% \mathrm{H}_{2} \mathrm{O}_{2}$ in absolute methanol (5 min each change) and rinsing in water. Immunohistochemical analysis was performed using the streptavidin-biotin technique (streptavidin-biotin complex, SABC; DAKO, Carpinteria, USA). The reaction was incubated with monoclonal antibodies: Rb-1 (DAKO) at a dilution 1:50 for $60 \mathrm{~min}$, antigen retrieval by microwaves, $0.1 \mathrm{M} \mathrm{pH} 10$ Tris-EDTA for $10 \mathrm{~min}$; $\mathrm{WAF}_{1}(\mathrm{DAKO})$ at a dilution 1:50 for $20 \mathrm{~min}$, antigen retrieval by steamer, $\mathrm{pH} 8$ EDTA. Careful rinses were performed with several changes of PBS between each stage of the procedure. The sections were incubated with diaminobenzidine (Sigma Chemical CO, St. Louis, MO, USA), then counterstained lightly with Mayer's hematoxylin, dehydrated in a graded ethanol series, allowed to dry in air and mounted with Permount mounting medium (Fisher Scientific Company, Pittsburgh, PA, USA).

For counting of labeled cells, representative areas of the tumor where staining was constant were selected. p21- and pRb-positive cells were counted under a light microscope using a counting grid in an area of $0.25 \mathrm{~mm}^{2}$ at a final magnification of $\times 1,000$ to avoid recounting of the same histological fields. A total of 1,000 cells for the two markers were counted in each specimen. Each nucleus was counted as one unit and the number of positive cells for each case was obtained by the sum of labeled nuclei. A sample was considered to be positive for $\mathrm{pRb}$ and $\mathrm{p} 21$ when at least $10 \%$ of the cells were stained.

The results were analyzed statistically by the Student's t-test, Mann-Whitney U-test and chi-square test, with the level of significance set at $95 \%(\alpha=0.05)$. The research project was approved by the Research Ethics Committee of the Federal University of Rio Grande do Norte (Process \# 68/03).

\section{RESULTS}

Of the 33 samples that were positive for the human $\beta$ globin gene (Figure 1A), HPV 16 and/or HPV 18 were detected in $11(33.33 \%$ ) (Figure 1B). HPV 18 was identified in 9 (81.81\%) cases and HPV 16 and 18 were simultaneously present in 2 (18.19\%) cases.

pRb was expressed in 9/11 (81.82\%) HPV-positive tumors and in 15/22 (68.19\%) HPV-negative cases (Figure 2A). Expression of p21 was observed in 5/11 (45.45\%) HPVpositive tumors and in 7/22 (31.82\%) HPV-negative tumors (Figure 2B). Statistical analysis revealed a significant 

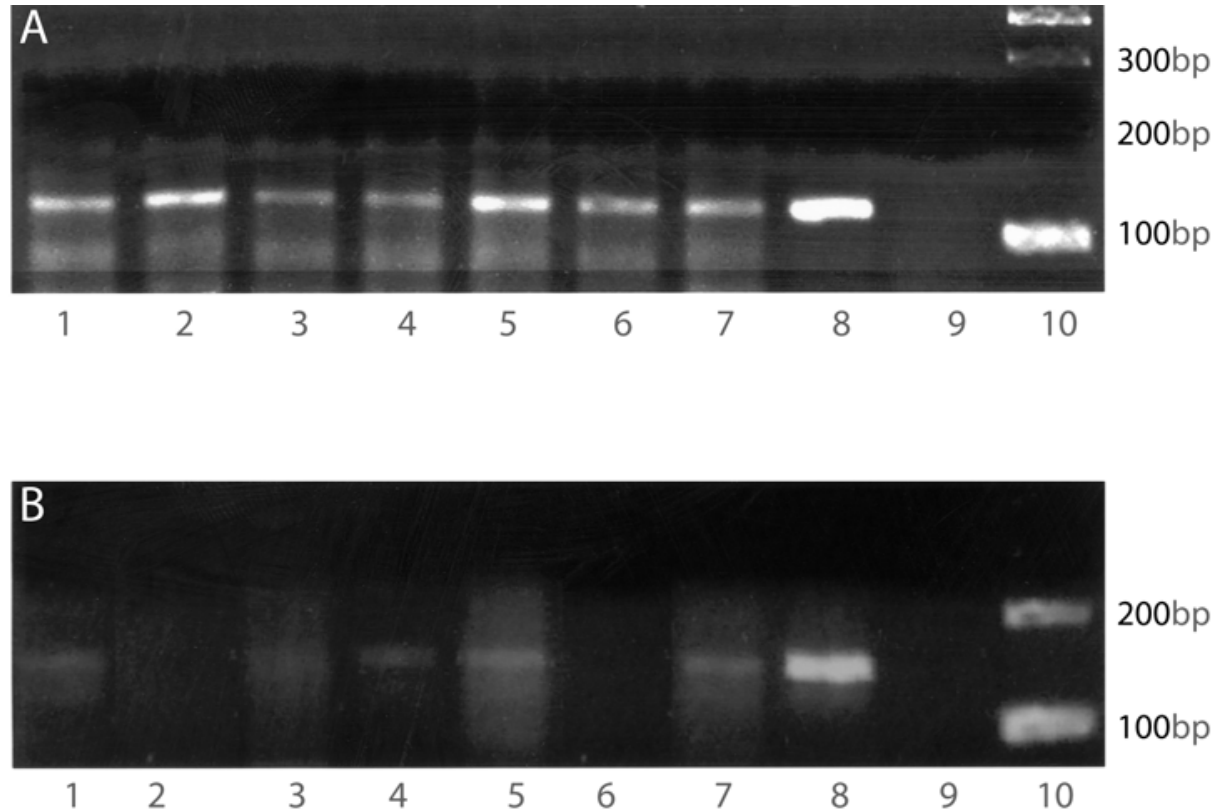

FIGURE 1- DNA detection by PCR. A: Detection of b-globin gene DNA. Lanes 1-7, samples from patients; lane 8, C33 cell DNA without HPV infection; lane 9, negative control $\left(\mathrm{H}_{2} \mathrm{O}\right)$; lane 10, molecular marker (100 bp); B: Detection of HPV DNA in samples from patients with OSCC. Lanes 1-7, samples from patients; lane 8, HeLa cell DNA infected with HPV 18; lane 9, negative control $\left(\mathrm{H}_{2} \mathrm{O}\right)$; lane 10 , molecular marker (100 pb)
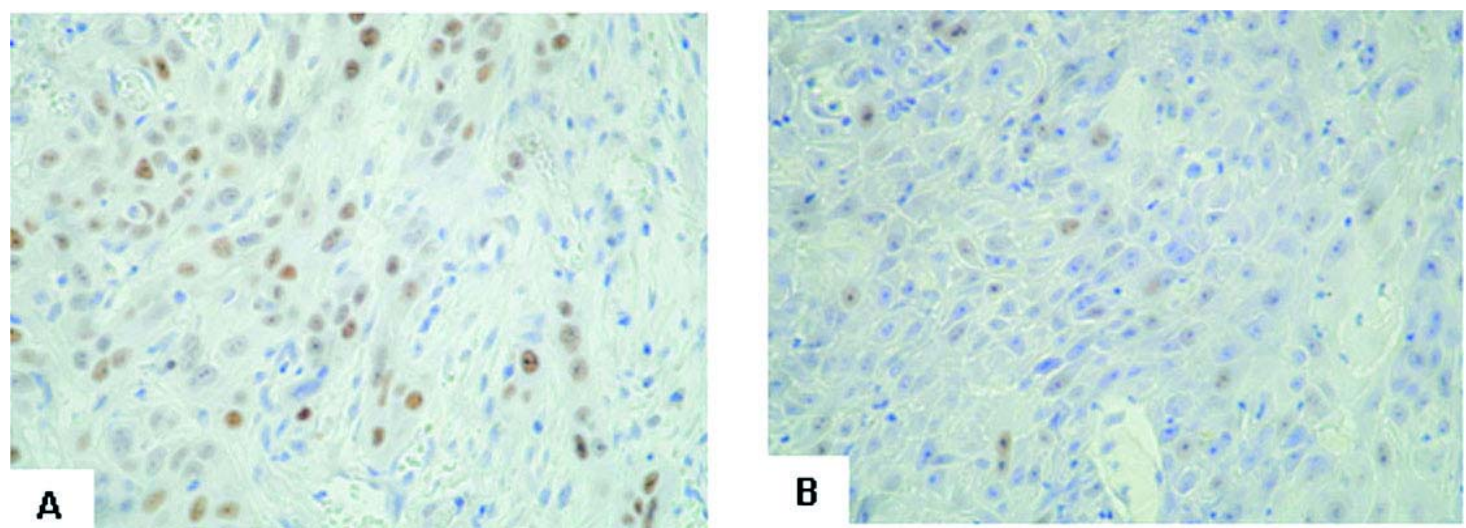

FIGURE 2- Immunohistochemical staining. A: Immunohistochemical staining for $\mathrm{pRb}$ in OSCC. Most tumor cells show intense nuclear staining $(\mathrm{SABC}, \times 200)$; B: Immunohistochemical staining for p21 in OSCC. The tumor cells show weak nuclear staining $(S A B C, \times 200)$.

association between the presence of HPV and immunohistochemical expression of $\mathrm{pRb}(\mathrm{p}=0.044)$. With respect to the expression of protein $\mathrm{p} 21$, no significant association was observed between the expression of this protein and the presence of the virus $(p=0.416)$.

\section{DISCUSSION}

This study investigated paraffin-embedded OSCC specimens for the presence of HPV by PCR. HPV DNA was detected in 11 (33.33\%) of the 33 OSCC cases evaluated. This percentage is compatible with data reported elsewhere ${ }^{14-16}$. However, it is extremely difficult to compare the results of different reports on HPV in the oral mucosa because of variations in parameters, such as type of sample (tissue extracted by biopsy, scraping), preparation method (fresh, frozen or fixed), ethnic difference between patients, geographic differences, and sensitivity of the methods used. Iftner, et al. ${ }^{7}$ have also reported that differences in DNA extraction procedures and in transport and storage of the clinical samples, and especially the use of different DNA polymerases for PCR, may affect the performance of the assays.

The most widely used primers are the generic primer pairs GP5+/GP6+ and MY09/MY11, which are able to amplify various virus types. In the present study, we used the GP5+/ GP6+ primer pair because, in addition to detecting a variety of virus types, it amplifies a small fragment (140 bp). This fact is important when evaluating archived paraffinembedded tissue, as done in the present study, which may show marked DNA fragmentation in some cases. 
In the present study, only HPV 16 and HPV 18 were detected, which is in agreement with the findings of previous studies $^{3,5,8,10,20}$. HPV 18 was present alone in most cases (9/ $11,81.81 \%$ ) and was detected together with HPV 16 in 2 (18.19\%) of the 11 cases. These results agree with those reported by other investigators who detected HPV 18 in most of their samples ${ }^{3,20}$. However, HPV 16 was the most frequent type in other studies ${ }^{2,5-7}$.

In view of the complexity of the biological behavior of malignant tumors, knowledge of the abnormalities that compromise the cell-cycle regulatory machinery is of paramount importance. In this respect, the study of regulatory proteins, such as p21 and pRb, may help identifying malignant tumors in amore accurate manner. In the present study, expression of p21 was detected in 5 (45\%) of the 11 HPV-positive tumors and in 7 (31.8\%) of the 22 HPV-negative tumors, with no significant difference between groups. These findings suggest that the presence of HPV is not sufficient to evaluate the relationship between viral proteins and cell-cycle regulatory proteins such as p21. Another important cell-cycle regulatory protein is $\mathrm{pRb}$, which also shows an important relationship with HPV. Viral oncoprotein E7 plays a relevant role in tumor progression by binding to protein $\mathrm{pRb}$, thus releasing transcription factor E2F which, in turn, activates the transcription of genes that promote cell-cycle progression and cell proliferation as cited earlier ${ }^{4}$. In the present study, a significant difference in the immunohistochemical expression of pRb was observed between HPV-positive (9/11, 81.8\%) and HPV-negative tumors $(15 / 22,68.2 \%)$.

Lim, et al. ${ }^{7}$ examined the alterations of molecules within the $\mathrm{pRb}$ pathway by looking at the presence of homozygous deletions in p16(INK4A) and the expression patterns of pRb, cyclin D1 and CDK4, as well as the presence of HPV. pRb overexpression was found in 20/20 samples, the expression was mainly observed in all layers of the epithelia, particularly in the basal layer where cells are actively dividing, and aberrant pRb expression was found in 12/20 samples. Strikingly, HPV was present in all samples, suggesting that it plays a significant role in driving oral carcinogenesis. Notably, 17/20 of the samples showed more than one alteration in the pRb pathway. However, Lim, et al. ${ }^{7}$ did not find any significant relationship between the presence of HPV, homozygous deletion of p16(INK4A) and overexpression of pRb, cyclin D1 and CDK4. Taken together, these data demonstrate that alterations in the pRb pathway are a common event and involve the aberration of more than one molecule within the pathway. Furthermore, the presence of HPV in all samples suggests that HPV infection may play an important role in oral carcinogenesis.

Nevertheless, Nemes, et al. ${ }^{9}$ found no significant difference in the immunohistochemical expression of $\mathrm{pRb}$ when comparing carcinoma groups with and without HPV. Yamamoto, et al. ${ }^{19}$, evaluating cases of colorectal cancer, observed that the increase in pRb levels was associated with the hyperphosphorylated form of the protein (inactive form). However, $\mathrm{Xu}$, et al..$^{18}$ stated that antibodies against $\mathrm{pRb}$ label both the phosphorylated and non-phosphorylated form of the protein.

The present results regarding the immunohistochemical expression of $\mathrm{pRb}$ suggest a higher possibility of HPV infection in OSCC cases presenting higher $\mathrm{pRb}$ expression, and that binding of HPV protein E7 to pRb is likely to induce the accumulation of the latter, thus leading to its inactive form.

\section{CONCLUSIONS}

In the present study, HPV DNA was detected in a low percentage of OSCC cases (33.33\%), suggesting that HPV plays a key role in the development and progression of only a small subgroup of these carcinomas. HPV 18 was the most prevalent type, suggesting that this viral type was specifically related to the development of OSCC in the studied sample. The immunohistochemical expression of protein $\mathrm{pRb}$ was significantly higher in HPV-positive OSCC than in HPV-negative tumors, this finding indicating an important relationship between the virus and $\mathrm{pRb}$ in these tumors. No difference in the immunohistochemical expression of p21 was observed between HPV-positive and HPVnegative OSCC cases. It is likely that HPV infection and immunohistochemical expression of p21 represent independent factors in these tumors.

\section{REFERENCES}

1- Campisi G, Panzarella V, Giuliani M, Lajolo C, Di Fede O, Falaschini $\mathrm{S}$, et al. Human Papillomavirus: its identify and controversial role in oral oncogenesis, premalingant and malignant lesions (review). Int J Oncol. 2007;30:813-23.

2- Cho NM, Kim YT, Kim JW. Alteration of cell cycle in cervical tumor associated with human papillomavirus: cyclin-dependent kinase inhibitors. Yonsei Med J. 2002;43:722-8.

3- Giovannelli L, Campisi G, Lama A, Giambalvo O, Osborn J, Margiotta V, et al. Human Papillomavirus DNA in oral mucosal lesions. J Infect Dis. 2002;185:833-6.

4- Helt, AM, Funk JO, Galloway, DA. Inactivation of both the retinoblastoma tumor suppressor and p21 by the human papillomavirus type $16 \mathrm{E} 7$ oncoprotein is necessary to inhibit cell cycle arrest in human epithelial cells. J Virol. 2002;76:10559-68.

5- Ibieta BR, Lizano M, Mendivil MF. Human papillomavirus in oral squamous cell carcinoma in a Mexican population. Oral Surg Oral Med Oral Pathol Oral Radiol Endod. 2005;99:311-5.

6- Iftner T, Villa LL. Chapter 12: Human papillomavirus technologies. J Natl Cancer Inst Monogr. 2003;31:80-8.

7- Lim KP, Hamid S, Lau SH, Teo SH, Cheong SC. HPV infection and the alterations of the HPV infection and the alterations of the pRB pathway in oral carcinogenesis. Oncol Rep. 2007;17:1321-6.

8- Muzio L, Campisi G, Giovannelli L, Ammatuna P, Greco I, Staibano $\mathrm{S}$, et al. HPV DNA and survivin expression in epithelial oral carcinogenesis: a relationship? Oral Oncol. 2004;40:736-41. 
9- Nemes JA, Deli L, Nemes Z, Marton IJ. Expression of p16 $6^{\mathrm{INK} 4 \mathrm{~A}}$, $\mathrm{P} 53$, and $\mathrm{Rb}$ proteins are independent from the presence of human papillomavirus genes in oral squamous cell carcinoma. Oral Surg Oral Med Oral Pathol Oral Radiol Endod. 2006;102:344-52.

10- Rivero ERC, Neves AC, Silva-Valenzuela MG, Sousa SOM, Nunes FD. Simple salting-out method for DNA extraction from formalinfixed, paraffin-embedded tissues. Pathol Res Pract. 2006;202:523-9.

11- Roda Husman AM, Walboomers JM, van Den Brule AJ, Meijer CJ, Snijders PJ. The use of general primers GP5 and GP6 elongated at their 3' ends with adjacent highly conserved sequences improves human papillomavirus detection by PCR. J Gen Virol. 1995;76:105762.

12- Saiki RK, Scharf S, Faloona F, Mullis KB, Horn GT, Erlich HA, et al. Enzymatic amplification of beta-globin genomic sequences and restriction site analysis for diagnosis of sickle cell anemia. Science. 1985;230:1350-4

13- Sambrook J, Russel D. Molecular cloning. Philadelphia: CSHL Press; 2001.

14- Saranath D, Tandle AT, Teni T, Dedhia PM, Borges AM, Parikh D, et al. p53 inactivation in chewing tobacco-induced oral cancers and leukoplakias from India. Oral Oncol. 1999;35:242-50.

15- Scully C. Oral squamous cell carcinoma; from an hypothesis about a virus, to concern about possible sexual transmission. Oral Oncol. 2002;38:227-34.

16- Summersgill KF, Smith EM, Kirchner HL, Haugen TH, Turek LP. p53 polymorphism, human papillomavirus infection in the oral cavity, and oral cancer. Oral Surg Oral Med Oral Pathol Oral Radiol Endod. 2000;90:334-9

17- Todd R, Hinds PW, Munger K, Rustgi AK, Opitz OG, Suliman Y, et al. Cell cycle dysregulation in oral cancer. Crit Rev Oral Biol Med. 2002;13:51-61.

18- Xu HJ, Xu K, Zhou Y, Li J, Benedict WF, Hu SX. Enhanced tumor cell growth suppression by an N-terminal truncated retinoblastoma protein. Proc Natl Acad Sci U S A. 1994;91:9837-41.

19- Yamamoto H, Monden T, Ikeda, Izawa H, Fukuda K, Fukunaga $\mathrm{M}$, et al. Coexpression of cdk2/cdc2 and retinoblastoma gene products in colorectal cancer. Br J Cancer. 1995;71:1231-6.

20- Zhang ZY, Sdek P, Cao J, Chen WT. Human papillomavirus type 16 and 18 DNA in oral squamous cell carcinoma and normal mucosa. Int J Oral Maxillofac Surg. 2004;33:71-4. 